\title{
EFEKTIVITAS DAUN GAMBIR ( UNCARIA GAMBIR ROXB ) UNTUK MENURUNKAN HALITOSIS YANG DISEBABKAN OLEH PLAK Studi di Panti Asuhan dan Pondok Pesantren Zuhriyah, Sleman, Yogyakarta
}

Irfan*, Yayun Siti Rochmah ${ }^{* *}$, Moh Yusuf**, Grahita Aditya ${ }^{* *}$

\begin{tabular}{|c|}
\hline Keywords: \\
Gambir, Halitosis, \\
Volatile Sulfur Compound \\
(VSC), hydrogen \\
sulfide $\left(\mathrm{H}_{2} \mathrm{~S}\right)$, methyl \\
mercaptan $\left(\mathrm{CH}_{3} \mathrm{SH}\right)$ dan \\
dimethylsulfide $\left(\mathrm{CH}_{3}\right)_{2} \mathrm{~S}$ \\
\hline
\end{tabular}

\section{ABSTRACT}

Introduction: Halitosis is the smell of bad breath that comes out of the mouth. Gambir contained catechins which is a material that helps in inhibited bacteria and VSC (Volatic Sulfur Compound) as the cause of halitosis.

Purpose: The aim of research to assess the effectiveness of gambir leaves against halitosis is caused by plaque.

Methods: The method in this research is pre experimental research with 18 research subjects students. Halitosis parameter measurements made before and after the use of gambir for 3 days. VSC gas is measured using the tool "Oralchroma". Statistical data processing is done with the Wilcoxon test ( $p$ $<0.05$ as significant level).

Results: There were decreased levels in each of the gas before and after gargling on treatment. $\mathrm{H}_{2} \mathrm{~S}$ levels down to $100 \%, \mathrm{CH}_{3} \mathrm{SH}$ fell by $43 \%,\left(\mathrm{CH}_{3}\right)_{2} \mathrm{~S}$ down $24 \%$. The three gas is visible gas reduction percentage is the highest $\mathrm{H} 2 \mathrm{~S}$ and the lowest is $\left(\mathrm{CH}_{3}\right)_{2} \mathrm{~S}$. Wilcoxon test results obtained $\mathrm{H}_{2} \mathrm{~S}$ sig $0.109(\mathrm{p}$ $<0.05), \mathrm{CH}_{3} \mathrm{SH}$ sig $0.005(\mathrm{p}<0.05)$ and $\left(\mathrm{CH}_{3}\right)_{2} \mathrm{~S}$ sig $0.009(\mathrm{p}<0.05)$.

Conclusion: Gambir leaf decoction is effective against halitosis is caused by plaque.

\section{PENDAHULUAN}

Halitosis merupakan penyakit yang banyak di jumpai, berdasarkan riset yang di lakukan oleh Eldarrat, Alkhabuli dan malik tahun 2008 menyimpulkan bahwa dari 600 kuissoner yang dibagikan $44 \%$ pria dan 54 $\%$ wanita yang mengalami masalah pada bau mulut mereka sendiri dan $2 \%$ tidak mempunyai masalah pada bau mulut ${ }^{1}$.

Bau mulut bersumber dari bakteri dan protein, oleh karena itu pada dasarnya adalah tingkat keparahan dari individu satu dengan yang lain berbeda ${ }^{2}$. Halitosis Berat dapat mengganggu kenyaman orang lain saat berinteraksi sosial, mempengaruhi rasa percaya diri dan mengurangi performa pada saat berinteraksi sosial ${ }^{3}$. Bakteri yang berasal dari rongga mulut sendiri seperti plak, bakteri yang berasal dari poket yang dalam dan bakteri yang berasal dari lidah akan mengeluarkan zat-zat enzim yang berpotersi sangat besar menimbulkan halitosis ${ }^{4}$.

Halitosis adalah adanya bau mulut yang di hembuskan melalui udara yang berasal dari oral dan non oral ${ }^{2}$. Hal ini dapat dicegah dengan merawat kebersihan dalam rongga mulut melalui perawatan sumber-sumber penyebab di dalam rongga mulut yang dapat secara efektif memecahkan masalah-masalah nafas tak sedap. Salah satu cara yang dapat dilakukan untuk mencegah dan menghilangkan halitosis yaitu dengan penggunaan cara tradisional $^{5}$.

Gambir mempunyai kandungan terbanyak fenol dan katekin. Kemampuan bakterisidal katekin dengan caramendenaturasi protein dari bakteri, dapat membunuh ataupun menghambat pertumbuhan bakteri ${ }^{6,7}$.

Tujuan penelitian ini adalah Untuk mengetahui efektivitas daun gambir terhadap halitosis yang di sebabkan oleh plak. 


\section{METODE PENELITIAN}

Jenis penelitian merupakan Pra Experimental dengan rancangan penelitian one group pre test post test design. Penelitian ini dilakukan di Laboratorium Halitosis RSGM Prof. Soedomo, Yogyakrta. Penelitian dilakukan selama bulan Desember 2014. Pengambilan sampel pada penelitian ini menggunakan insidentil consecutive dengan memperhatikan kriteria inklusi dan eksklusi. Pada penelitian ini terdapat 18 santri sebagai objek yang akan diteliti.

Instrumen penelitian dan bahan penelitian yang digunakan yaitu Gambir, formulir informed concent, formulir isian untuk hasil pemeriksaan intra oral, kaca mulut, sonde, pinset, bengkok, kapas, sarung tangan, masker, alkohol $70 \%$, aquades, oralchroma.

Subjek mengisi formulir inform consent untuk ketersediaannya menjadi objek penelitian. Santri melakukan pengukuran $\mathrm{OHI}-\mathrm{S}$ untuk mengetahui indeks plak yang akan di jadikan sampel dalam penelitian. Santri diberikan disclosing agent terlebih dahulu, setelah itu santri bermukur kemudian dilihat menggunakan mouth mirror. Setelah diukur santri yang skor indeks plak sedang dan berat akan memenuhi kriteria inklusi yang akan dijadikan sebagai sampel dalam penelitian.

Setiap sampel akan di instruksikan untuk dilakukan pengukuran halitosis sebelum dan sesudah menggunakan alat Oralchroma untuk mengetahui kadar Volatile Sulfur Compound (VSC). Berkumur dengan rebusan daun gambir untuk mengetahui efektivitas terhadap halitosis.
Setiap pengambilan data menggunakan alat oralchroma sampel di wajibkan untuk menghindari kegiataan oral selama 2 sebelum pengambilan data. Subyek di instruksikan untuk menutup mulut dan bernafas melalui hidung. Disposable syringe plastik $1 \mathrm{ml}$ dimasukkan ke dalam rongga mulut, melalui bibir dan gigi, bibir tetap tertutup. Perlahan plunger syringe ditarik, lalu didorong, kemudian ditarik untuk kedua kalinya, baru dikeluarkan dari rongga mulut. Lalu jarum dipasangkan ke syringe, sampel gas dalam syringe diinjeksikan ke dalam inlet "Oralchroma" dan pengukuran akan berlangsung secara otomatis ${ }^{8}$.

Data yang diperoleh dilakukan analisa data. Uji normalitas data dengan menggunakan uji Saphiro-Wilk dan uji homogenitas menggunakan Levene Tes. Data hasil kadar gas hydrogen sulfide $\left(\mathrm{H}_{2} \mathrm{~S}\right)$, methyl mercaptan $\left(\mathrm{CH}_{3} \mathrm{SH}\right)$ dan dimethylsulfide $\left(\mathrm{CH}_{3} \mathrm{SCH}_{3}\right)$ tidak berdistribusi normal dan tidak homogen sehingga menggunukan non parametrik uji wilcoxon.

\section{HASIL PENELITIAN}

Data yang dikumpulkan berupa kadar Volatile Sulfur Compound (VSC) yang terdapat dalam rongga mulut menggunakan alat Oralchroma mempunyai jumlah Kadar VSC yang diukur terdiri dari hydrogen sulfide $\left(\mathrm{H}_{2} \mathrm{~S}\right)$, methyl mercaptan $\left(\mathrm{CH}_{3} \mathrm{SH}\right)$ dan dimethylsulfide $\left(\mathrm{CH}_{3} \mathrm{SCH}_{3}\right)$. Rerata Hasil pengukuran kadar VSC tersebut dapat dilihat pada Tabel 1.

Tabel 1. Hasil pengukuran kadar VSC sebelum dan sesudah perlakuan

\begin{tabular}{ll} 
Kadar VSC & Rerata \pm Simpangan Baku \\
\hline $\mathrm{H}_{2} \mathrm{~S}$ pre & $0.0406 \pm 0.10474$ \\
$\mathrm{H}_{2} \mathrm{~S}$ post & $0.0000 \pm 0.00000$ \\
\hline $\mathrm{CH}_{3} \mathrm{SH}$ pre & $3.1617 \pm 2.31157$ \\
$\mathrm{CH}_{3} \mathrm{SH}$ post & $1.7867 \pm 1.85505$ \\
$\left(\mathrm{CH}_{3}\right)_{2} \mathrm{~S}$ pre & $3.9572 \pm 2.24750$ \\
$\left(\mathrm{CH}_{3}\right)_{2} \mathrm{~S}$ post & $3.0039 \pm 2.69617$ \\
\hline
\end{tabular}


Tabel 2. Hasil uji Wilcoxon

\begin{tabular}{ll} 
& Sig. \\
$\mathrm{H} 2 \mathrm{~S}$ & 0.109 \\
$\mathrm{CH} 3 \mathrm{SH}$ & $0.005^{*}$ \\
\hline$(\mathrm{CH} 3) 2 \mathrm{~S}$ & $0.009^{*}$ \\
\hline
\end{tabular}

(*) signifikan $=p<0,05$

Tabel 1 menunjukkan bahwa hasil pengukuran ketiga gas VSC dengan Oralchroma, memperlihatkan adanya penurunan masing-masing gas sebelum dan sesudah berkumur. Pada gas $\mathrm{H}_{2} \mathrm{~S}$ mengalami penurunan dari $0,406 \mathrm{ng} / \mathrm{ml}$ menjadi 0,000 $\mathrm{ng} / \mathrm{ml}$ turun $100 \%$. CH3SH mengalami penurunan dari $3,161 \mathrm{ng} / \mathrm{ml}$ menjadi $1,786 \mathrm{ng} /$ $\mathrm{ml}$ turun $43 \%$. Sedangkan $\left(\mathrm{CH}_{3}\right)_{2} \mathrm{~S}$ mengalami penurunan dari $3,957 \mathrm{ng} / \mathrm{ml}$ menjadi 3,003 $\mathrm{ng} /$ $\mathrm{ml}$ turun $24 \%$.

Hasil dari uji Wilcoxon dalam tabel 2 yang bertujuan untuk menguji signifikansi perbedaan rata-rata penurunan gas-gas VSC sebelum dan sesudah berkumur dengan Rebusan daun gambir. Kadar $\mathrm{CH}_{3} \mathrm{SH}(\mathrm{p}=0,005)$ dan $\left(\mathrm{CH}_{3}\right)_{2} \mathrm{~S}$ $(p=0,009)$ adalah signifikan karena $p<0,05$. Dan $\mathrm{H}_{2} \mathrm{~S}(\mathrm{p}=0,109)$ tidak signifikan karena jarak antara pre postnya yang terlalu kecil pada data.

\section{DISKUSI}

Berdasarkan pada Tabel 1 di dapatkan hasil bahwa Kadar VSC yaitu hydrogen sulfide $\left(\mathrm{H}_{2} \mathrm{~S}\right)$ memiliki rata-rata penurunan yang paling tinggi yaitu $100 \%$, methyl mercaptan $\left(\mathrm{CH}_{3} \mathrm{SH}\right)$ memiliki rata-rata penurunan tinggi kedua yaitu $43 \%$ dan dimethylsulfide $\left(\mathrm{CH}_{3} \mathrm{SCH}_{3}\right)$ memiliki penurunan yang paling rendah yaitu $24 \%$. Pada Kadar $\mathrm{H}_{2} \mathrm{~S}$ setelah dilakukan uji Wilcoxon hasilnya tidak signifikan dikarenakan jarak antara pre postnya yang terlalu kecil pada data, untuk kadar $\mathrm{CH}_{3} \mathrm{SH}$ dan $\mathrm{CH}_{3} \mathrm{SCH}_{3}$ setelah dilakukan uji Wilcoxon hasilnya signifikan. Penurunan Kadar VSC ini dikarenakan katekin dalam gambir mampu menghambat pembentukan insoluble glukan dari sukrosa oleh Gluosiltransferase (GTFs) yang berperan penting dalam pebentukan plak $^{11}$.

Gas-gas ini merupakan hasil produksi dari efektivitas bakteri-bakteri didalam mulut yang merupakan senyawa berbau tidak sedap dan mudah menguap ${ }^{8}$. Dalam penelitian yang menganalisa bakteri penghasil halitosis dan jenis halitosis, ditemukan bahwa Prevotella intermedia, Prevotella higrescens dan Treponame denticola, berkolerasi dengan kadar hidrogen sulfide, Dorphyromonas gingivalis, P.intermedia, dan Tannerella forsythensis berkolerasi dengan kadar metil merkaptan $^{10}$.

Berdasarkan hasil tersebut maka dapat disimpulkan bahwa daun gambir mempunyai efektifitas terhadap halitosis yang disebabkan oleh plak. Pada ketiga kadar VSC semuanya mengalami penurunan setelah berkumur dengan daun gambir. Hal tersebut sesuai dengan penelitian sebelumnya yang menyebutkan bahwa lama berkumur dengan rebusan daun gambir berpengaruh terhadap pembentukan plak gigi, Optimumnya dalam menurunkan pembentukan plak gigi yaitu berkumur selama 3 menit. Semakin lama berkumur dengan rebusan daun gambir terjadi juga titik jenuh artinya makin lama berkumur tidak mempunyai pengaruh terhadap penurunan pembentukan plak gigi dan berkumur kurang dari 3 menit juga kurang optimal dalam menurunkan plak gigi ${ }^{11}$. Daun gambir yang dapat menurukan plak, juga menurunkan kadar VSC pada halitosis. 
Kemampuan bakterisidal katekin dengan cara mendenaturasi protein bakteri, karena gugus fenol yang terkandung dalam katekin merupakan senyawa toksik, sehingga deret asam amino protein tetap utuh namun aktifitas biologiknya rusak, yang akhirnya tidak dapat melakukan fungsinya ${ }^{7}$.

Hasil penelitian ini menunjukkan penggunaan rebusan Gambir sebagai sediaan antiseptik dari katekin dapat mencegah plak pada gigi ${ }^{12}$. Senyawa fungsional gambir yaitu fenol dan katekin dapat berperan sebagai antioksidan, antibakteri dan antikarsinogenik alami. Daun gambir juga dapat sebagai antioksidan dan antibakteri dari turunannya metil ekstrack etanol ${ }^{9}$. Perbandingan antara obat kumur seperti klorheksidin, obat herbal seperti daun gambir jauh lebih aman karena tidak mengandung alkohol dan jarang menyebabkan efek samping apabila dipakai dalam jangka waktu yang lama.

Meskipun terbukti dapat menurunkan indeks halitosis, namun penelitian ini memiliki beberapa keterbatasan. Terdapat beberapa faktor perancu yang juga mempengaruhi tingkat halitosis dalam penelitian ini sukar yang dikendalikan yaitu faktor sistemik Seperti faktor pernafasan, penyakit pencernaan, penyakit hepar dan penyakit endokrin mampu menyebabkan halitosis ${ }^{4}$ karena memerlukan pemeriksaan penunjang yang kuat untuk mengetahui jenis penyakit tersebut dan biaya yang besar. Jumlah sampel yang kurang adekuat karena sampel yang mengikuti penelitian ini masih belum banyak, sehingga menjadi keterbatasan dalam penelitian menyebabkan variasi nilai berbagai komponen dalam VSC berbeda, sehingga tidak homogen. Dan nilai ini mengganggu hasil, karena hasilnya merupakan selisih pre dan post.

Hasil dari penelitian menunjukkan lama berkumur dengan rebusan daun gambir berpengaruh terhadap pembentukan plak gigi. Optimumnya dalam menurunkan pembentukan plak gigi yaitu berkumur selama 3 menit ${ }^{11}$. Daun gambir yang dapat menurukan plak, juga menurunkan kadar VSC pada halitosis. Jadi secara signifikan daun gambir efektif dalam menurunkan halitosis yang disebabkan oleh plak.

\section{KESIMPULAN}

1. Rebusan daun gambir efektif terhadap halitosis yang disebabkan oleh plak

2. Terjadi Penurunan indeks halitosis antara sebelum dan sesudah perlakuan pada Zat $\mathrm{CH}_{3} \mathrm{SH}(\mathrm{p}=0,005)$ dan $\left(\mathrm{CH}_{3}\right)_{2} \mathrm{~S}(\mathrm{p}=0,009)$ adalah signifikan.

3. Terjadi penurunan indeks halitosis anatara sebelum dan sesudah perlakuan pada zat $\mathrm{H}_{2} \mathrm{~S}(\mathrm{p}=0,109)$ adalah tidak signifikan

\section{DAFTAR PUSTAKA}

1. Eldarat A, Alkhabuli J, Malik A. 2008. The pravalence of Self-Reported Halitosis and Oral Hygiene Practise Among Libyan Student and Offices Workers. Libyan $\mathrm{J}$ Med. Faculty of Dentistry, University of Sharjah, Sharjah, UEA.

2. Widagdo Y \& Suntya K. 2014. Volatile sulfur compounds sebagai penyebab halitosis. Bagian IImu Penyakit Mulut Fakultas Kedokteran Gigi Universitas Mahasaraswati. Denpasar.

3. Hakim L. 2013 Penyebab Bau Mulut dan Cara Mengatasi Bau Mulut. http://www.ahlisyukur. com/2013/05/5-penyebab-bau-mulut-dan-cara mengatasi.html. Diakses 7 may 2013. 10:36 PM.

4. Curd ML, Thomas B. 2012. Halitosis: the multidisciplinary approach. International Journal of Oral Science (2012) 4, 55-63. Belanda.

5. Dalimartha, S. 2008. Atlas Tumbuhan Obat Indonesia. Jakarta: Pustaka Bunda, Grup Puspa Swara, Anggota IKAPI.

6. Hayani, E. 2003. Analisis Kadar Catechin dari Gambir Dengan Berbagai Metode. Buletin Teknik Pertanian 8 (1): 31- 32. Jember.

7. Dea, H. 2004. Daun Sirih sebagai Pasta Gigi Anti Bakteri. Dalam:http://www.kompas.com/ kompascetak/0309/24/iptek/578008.htm..Di unduh Maret 2014

8. Wijayanti,A., Rahardjo.A., Bahar. A. 2010. Perubahan Parameter Halitosis Setelah Penggunaan Siwak (SalvadoraPersica) Pada Santri Pondok Pesantren Tapak Sunanusia 11-13 Tahun. INA J DENT RES, Vol. 17 NO.2 September 2010: 43-47.jakarta.

9. Kresnawaty, I\& Zainuddin, A. 2009. Aktivitas 
antioksidan dan antibakteri dari derivatmetil ekstrak etanol daun gambir (Uncaria gambir), Jurnal Littri15(4), HIm. 145 - 151. Sumedang.

10. Tanaka M, dkk. 2004. Contribution of periodontal on tongue dorsa analyzed with analyzed with realtime PCR. Department of Preventive Dentistry, Graduate School of Dentistry, Osaka University, 1-8 Yamadaoka, Suita, Osaka 565-0871, Japan

11. Susilowati A, sumarawati T. 2012. Kajian Lama Kumur Air Rebusan Gambir (Uncaria gambir) terhadap Pembentukan Plak Gigi. Semarang: Bagian IImu Gigi dan Mulut Fakultas Kedokteran, UNISSULA/ Rumah Sakit Pendidikan Sultan Agung.

12. Lucida, dkk. 2007. Formulasi sediaan anti septic mulut dari katekin gambir. Jurnal Sains danTeknologi Farmasi. Vol 12(1). Padang. 